\title{
A CASE OF LAPAROSCOPIC TREATMENT OF THE RETROPERITONEAL ECTOPIC PREGNANCY
}

\author{
Bo-Ra Park, MD, Na-Hye Lee, MD, Chi-Ok Ann, MD, Hyun-Jin Shim, MD, Eun-Kyu Jo, MD, \\ Yun-Sook Kim, MD, Dong-Han Bae, MD \\ Department of Obstetrics and Gynecology, Soonchunhyang University Cheonan Hospital, Soonchunhyang University College of Medicine, Cheonan, Korea
}

Ectopic pregnancy accounts for approximately $2 \%$ of all pregnancies and is the most common cause of pregnancy-related mortality in the first trimester. Initial evaluation consists of $\beta$-hCG and pelvic ultrasonography. The fallopian tube is the most common location for an ectopic pregnancy. Other types of ectopic pregnancy include cornual, ovarian, cervical, scar, and abdominal pregnancy. In very rare cases, the abdominal pregnancy may be retroperitoneal. The diagnosis is seldom established before surgery and therapy is surgical resection of the ectopic mass. A 26-year-old woman visited our emergency department with sudden massive vaginal bleeding. She had undergone curettage 3 weeks before. But the transvaginal sonogram of the cul-de-sac revealed no fluid collection. She failed variable-dose methotrexate therapy. On laparoscopic operation, we found a cystic, conception-like structure in the retroperitoneum. Histology of resected structure showed chorionic villi. We describe this case with a brief review of the literature.

Keywords: Laparoscopy, Retroperitoneum, Ectopic pregnancy

자궁외임신은 자궁내막 이외의 부위에 임신이 되는 경우로, 난관이 가장 흔히 발생하는 부위이고, 이외에 난소, 복강, 심지어 후복막에도 발 생할 수 있다. 후복막에 발생하는 자궁외임신은 매우 드물어 3,372분만 에서 7,931분만당 1건으로 보고되고 있다[1]. 후복막임신의 발생장소는 더글라스와, 자궁의 후면, 간, 비장, 횡격막 등 매우 다양하게 보고되고 있다. 발생기전은 자궁내임신의 파열 후 배아가 후복막으로 이동한다는 설과 정상 자궁내임신이 자연적으로 후복막으로 전이된다는 두 가지 가 설이 있다[2].

본 증례는 내원 3주 전 무월경 5 주에 소파수술 후, 특이소견 없이 지 내던 26세 여성에서 일반적인 자궁외임신에서 볼 수 없는 급작스런 다 량의 질 출혈로, 초음파에서 자궁외임신으로 추정 진단 후 메토트렉세 이트 다회 요법을 시행하였으나, 베타 사람 융모 생식샘 자극호르몬 증 가 소견을 보여 복강경을 시행하여 우측 후복막에 착상된 자궁외임신으 로 최종 진단하여 치료한 매우 드문 예로 간단한 문헌 고찰과 함께 보고 하는 바이다.

$$
\begin{aligned}
& \text { 증 례 } \\
& \text { 환 자: 곽 O 정(26세), 미혼 } \\
& \text { 산과력: 2-0-0-2 (인공유산 2회) }
\end{aligned}
$$

월경력: 14 세에 초경을 시작하여 28일 주기로 규칙적이고 기간은 7일 이었으며, 양은 중등도였고 월경통은 없었다. 최종 월경일은 내원 8주 전이었다.

과거력: 환자는 의무기록에서 12년 전 본원 외과에서 개복하여 충수돌 기 절제술을 시행하면서 우측 난관 낭종절제술을 시행 받은 적 있었다. 내원 3 주 전 무월경 5 주에 개인 의원에 방문하였으며 임신 진단 후 소 파수술을 시행했고, 이후 간헐적인 하복부 불쾌감이 있었으나, 참을 만 한 정도였다고 한다. 소파수술 당시 자궁내막 내의 정상적인 임신낭을

Received: 2011. 2.19. Accepted: 2011.3.18.

Corresponding author: Yun-Sook Kim, MD

Department of Obstetrics and Gynecology, Soonchunhyang

University Cheonan Hospital, 23-20 Bongmyeong-dong,

Cheonan 330-721, Korea

Tel: +81-41-570-2150 Fax: +82-41-571-7887

E-mail: drsook@schmc.ac.kr

This is an Open Access article distributed under the terms of the Creative Commons Attribution Non-Commercial License (http://creativecommons.org/licenses/ by-nc/3.0/) which permits unrestricted non-commercial use, distribution, and reproduction in any medium, provided the original work is properly cited.

Copyright $\odot$ 2011. Korean Society of Obstetrics and Gynecology 


\section{KOREAN JOURNAL OF OBSTETRICS \& GYNECOLOGY}

KJOG Vol. 54, No. 4, 2011

확인하지는 않았다고 한다.

주소 및 현병력: 내원 당일 오전 7시경 갑자기 시작된 다량의 질 출혈을 주소로 응급실에 내원하였다.

신체검사 소견: 내원 당시 신체 검진에서 혈압 $90 / 60 \mathrm{~mm} \mathrm{Hg}$, 맥박

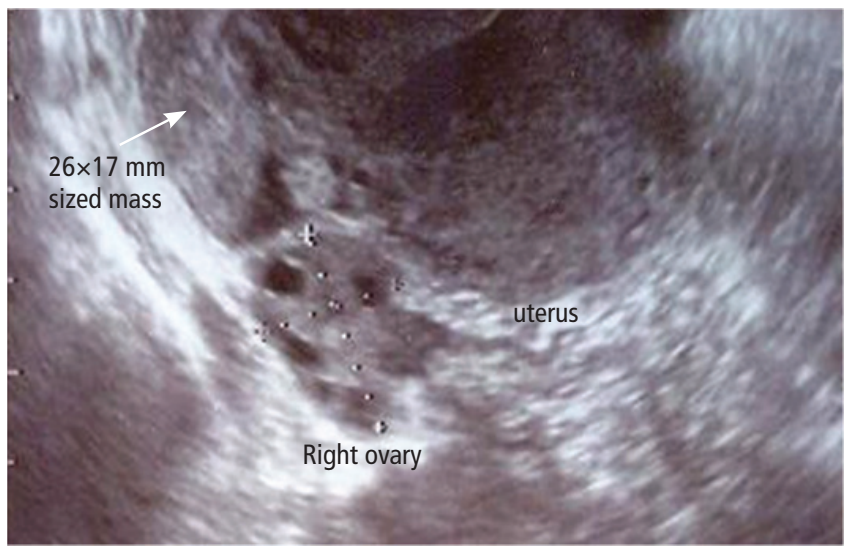

Fig. 1. Transvaginal sonogram showed the uterus, right ovary, and $26 \times 17$ $\mathrm{mm}$ sized right adnexal mass (arrow).
110 회/분, 호흡수 20 회/분, 체온 $36.6^{\circ} \mathrm{C}$ 였고 정신 상태는 명료하였다. 하복부에 통증은 거의 없었고, 미약한 압통은 있었으나, 반발통은 없었 다. 골반내진 소견에서 질 및 외음부는 이상 소견이 없었으며, 자궁경부 안쪽에서 다량의 출혈 소견을 보였다. 우측 부속기 부위를 건드리니 압 통을 호소하였고, 대형 패드 5장을 흠뻑 적시는 정도의 다량의 질 출혈 소견을 보였으나, 내진 중 출혈은 멈추었다.

검사실 검사 소견: 입원 당시 혈액검사에서 혈색소 $8.0 \mathrm{~g} / \mathrm{dL}$, 적혈구용 적 24.8\%이었고, 백혈구, 혈소판 수치는 정상이었다. $\beta-h C G$ 는 111.4 $\mathrm{mU} / \mathrm{mL}$ 였다. 혈액응고 검사, 간기능 검사, 신기능 검사에서 특이 소견 은 없었다. 간염 항원 검사와 매독 검사는 음성이었고, 혈액형은 B형 Rh (+)였다. 심전도 검사, 흉부 $X-$ 선 검사에서 특이 소견은 없었다.

초음파 소견: 경질 초음파 검사에서 양측 난소는 정상이었고, 자궁 내 막 두께는 $5 \mathrm{~mm}$ 로 균일하고 얇았으며 자궁 내강에 태낭이나 혈종은 관 찰되지 않았다. 더글라스와에 액체 저류 소견은 전혀 없었다. 우측 난소 옆으로 분리되어 있는 균질한 에코를 보이는 증가된 음영의 26×17 mm 크기의 혈종 모양의 종괴 소견이 관찰되어, 우측난관에 자궁외임신이 되었을 가능성을 배제할 수 없었다(Fig. 1).

입원 후 경과: 입원 후 질 출혈은 특별한 시술 없이 완전히 멈추었다. 입
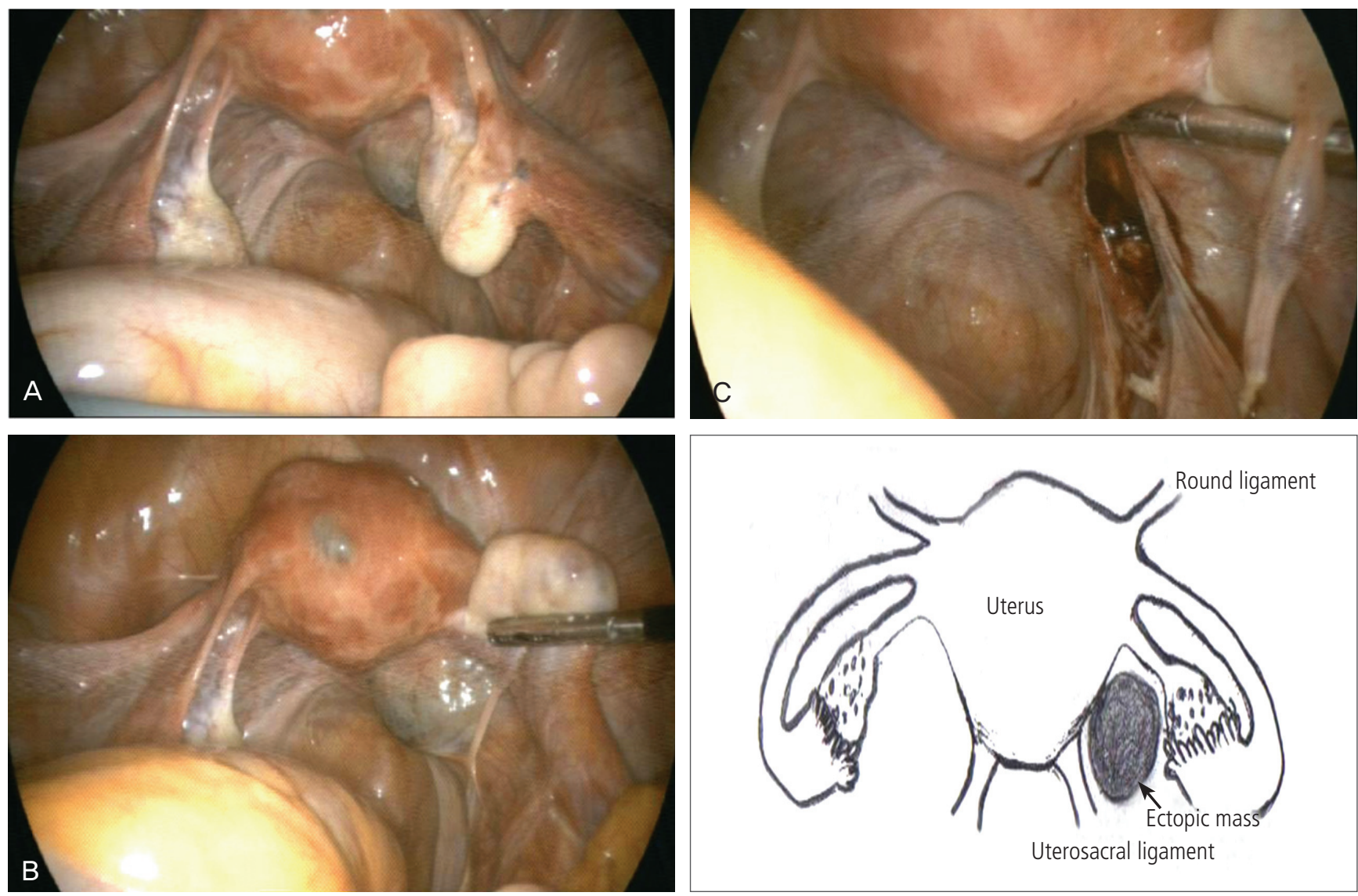

Fig. 2. (A) Laparoscopic operation findings showed both adnexas and no fluid collection of cul-de-sac. (B) About 25 mm sized dome like mass covered with retroperitoneum was shown between uterosacral ligament and right ovary at laparoscopy and diagram. (C) After resection of the retroperitoneal ectopic mass was seen. 


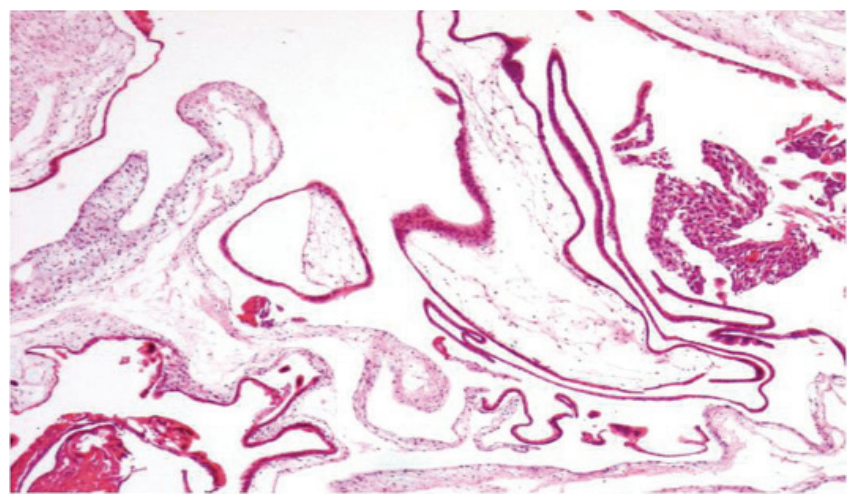

Fig. 3. The pathologic findings showed trophoblastic villi adherent to the retroperitoneum $\left(H \& E_{1} \times 100\right)$.

원 다음 날 $\beta-h C G$ 추적 검사에서 $109.7 \mathrm{mU} / \mathrm{mL}$ 로 비슷한 수치를 보 였고, 출혈은 전혀 없었다. 우측 난관 임신 의증 하에, 임신낭이 26×17 $\mathrm{mm}$ 크기로 작고, 복강 내에 혈복강 소견이 전혀 없고, $\beta$-hCG는 109.7 $\mathrm{mUU} / \mathrm{mL}$ 로 낮은 수치를 보여, 메소트레세이트-류코보린 다회 요법을 시 행하기로 하였다. 메소트레세이트 $50 \mathrm{mg}$, 류코보린 $5 \mathrm{mg}$ 을 격일로 근 주하였다. 메토트렉세이트 3회 근주하는 동안 $\beta-h C G$ 는 $84.8 \mathrm{mlU} / \mathrm{mL}$ 까지 감소하였으나, 이후 $98.6 \mathrm{mU} / \mathrm{mL}$ 까지 점차 증가하는 소견 보여 치 료 실패로 간주하고 복강경수술을 결정하였다.

수술 소견: 전신마취하에 제대 부위 $10 \mathrm{~mm}$ 투관침 삽입 후 골반 및 복 강 내부를 관찰하였다. 복강 내 혈복강 소견은 전혀 관찰되지 않았고, 좌측 난소와 난관은 정상 소견이었고, 우측 난소는 정상이었으나, 우측 난관의 난관채 부분은 과거수술로 제거되어 있었으나 파열이나 유착, 출혈 소견은 전혀 없었다. 우측 난소와 자궁천골인대 사이의 후복막 부 위에 약 $25 \mathrm{~mm}$ 크기의 임신낭처럼 보이는 파열 소견이 없는 둥근 낭종 이 발견되었으며, 복막을 절제해 보니 내부에 혈종과 수태산물처럼 보 이는 물질이 들어 있어 모두 제거해 주었다(Fig. 2).

수술 후 경과: 수술 1일째 $\beta-h C G$ 는 $65.2 \mathrm{mlU} / \mathrm{mL}$, 3일째 $43.1 \mathrm{mlU} / \mathrm{mL}$ 로 감소하여 수술 3일째 퇴원하였고, 퇴원 2주 후 외래 검사에서 1.5 $\mathrm{mlU} / \mathrm{mL}$ 까지 감소하였고, 수술 4주 후 정상월경이 돌아왔다

병리조직학적 소견: 생검된 조직의 현미경적 검사에서 융모막 융모 (chorionic vilili)가 관찰되어 후복막에 착상된 자궁외임신으로 확진되었 다(Fig. 3).

\section{고 찰}

자궁외임신은 산부인과 영역에서 흔한 응급 질환으로 임신 전반기 모 성 사망의 원인이 될 수 있고, 발생빈도는 100명의 가임 여성 중 3-4명 정도이며 10-20\%는 재발된다고 한다. 난관에 발생하는 빈도가 가장 많 으며, 그 외 복강 내, 자궁경부, 난소 및 인대 등에서도 발생한다[3].

복강임신은 약 1,000 여 년 전에 문헌에 최초로 언급된 이래 지속적인 증례 보고가 있었고, 1942년 Studdiford가 일차성과 이차성 복강임신 진
단 기준을 확립하여 현재까지 통용되고 있다. 일차성 복강임신으로 진 단하려면 다음 세 가지 조건을 만족해야 한다. 첫째, 양측 난관과 난소 가 정상이고 최근 또는 오래된 손상의 증거가 없어야 하며, 둘째, 자궁 복막 간 누공의 증거가 없어야 하고, 마지막으로 착상 부위가 복막에 한 정되고, 난관에 일차로 착상이 된 후 이차로 복막에 착상이 되었다는 가 능성을 배제할 수 있어야 한다. 특히 진행된 임신인 경우 일차성과 이차 성 복강임신을 구별하기는 쉽지 않기 때문에 Friedrich 등은 위의 진단 기준에서 복강 내 착상 부위의 조직학적 검사에서 임신 12주 이내에 융 모막융모가 발견되어야 일차성 복강임신으로 볼 수 있다고 하였다[4]. 하지만 대부분의 경우 일차성과 이차성 복강임신의 감별은 자궁 부속기 와 자궁에 대한 조직학적 검사를 시행해야만 판단할 수 있다[5].

복강내임신은 모성 사망률이 매우 높은데 이는 출혈, 감염, 패혈증, 빈 혈, 범발성 혈관 내 응고장애, 폐색전증, 태아 장골이 모체 장기를 관통 하여 발생하는 누공, 폐부종, 복막염, 혈종 등과 같은 심각한 합병증을 동반하기 때문이며, 몇몇 경우에서는 모체의 갑작스런 사망이 첫 증상 으로 나타나기도 한다[6,7]. 후복막에 발생하는 자궁외임신은 매우 드물 어 3,372분만에서 7,931분만당 1건으로 보고되고 있다[1]. 후복막임신 의 발생장소는 더글라스와, 자궁의 후면, 간, 비장, 횡격막 등 매우 다양 하게 보고되고 있다. 발생기전은 자궁내임신의 파열 후 배아가 후복막 으로 이동한다는 설과 정상 자궁내임신이 자연적으로 후복막으로 전이 된다는 두 가지 가설이 있다[2].

일차적인 착상을 증명하기 위해서는 자궁과 난소에 최근 또는 과거 손상이 전혀 없어야 하고, 자궁과 복강 사이에 누공의 증거가 없어야 하 는데 이런 경우는 거의 없다. 이렇게 자궁 이외 부위에 착상이 일어나는 이유는 골반염, 난관성형술, 난관결찰술, 인공유산, 난관기형, 그리고 자 궁 내 장치를 착용한 경우다. 복강임신은 고령, 유색인종 그리고 불임여 성에서 좀 더 흔히 나타난다. 1975년의 한 보고에서는 복강임신의 $79 \%$ 가 유색인종이며 평균연령이 31.5세인 것으로 보고하였다[8].

본 증례의 경우 복강경수술 소견에서 자궁, 양측 난소와 난관 모두 파 열, 유착 소견이 전혀 없고, 혈복강 소견이 전혀 없었다. 환자 과거력에 서 이전에 2회의 인공유산의 경험이 있어 이전 소파수술에 의해 자궁의 후벽과 후복막 사이에 누공이 형성되어 이 부위를 통해 배아가 후복막 쪽으로 이동하여 후복막에 착상이 되었을 가능성이 있다.

복강임신의 증상은 특징적이지 않고, 임신 초기에 불쾌감을 호소하는 정도이다. 임신낭이 점점 커짐에 따라 임신낭을 싸고 있는 복막의 표면 에 장력이 증가하여 동통을 유발하지만 침상 안정이나 일시적인 입원 치료로 증상이 완화되기도 한다[9]. 대다수의 경우 복통을 호소하며 정 도는 ‘불편감'에서부터 ‘참을 수 없는 통증'에 이르기까지 다양하고, 초 기에는 하복부에 국한되며, 질 출혈, 오심, 구토, 전신쇠약감을 호소하는 경우도 있고 파열이 된 경우 파열부위에 따라 혈복강에 의한 극심한 복 통에서 상당양의 질 출혈까지 다양하다. 복강 내에서 임신이 진행된 경 우 비정상적인 태위를 보이며 자궁은 태아와 분리되어 촉지되고 자궁경 부는 태아의 반대쪽으로 밀리며 거상된다[10].

상기 환자의 경우 복강 내로의 파열은 없어 혈복강에 의한 하복통은 없었으나, 소파수술 후 본원 입원 전까지 참을 만한 정도의 간헐적인 하 
복부 불쾌감이 자주 있었는데, 이는 임신낭을 싸고 있는 후복막 표면의 장력이 증가하여 동통을 유발한 것으로 보이며, 내원 당일에는 자궁경 부 쪽으로 다량의 질 출혈이 있었다. 최근에는 혈청 베타 사람 융모 생 식샘 자극호르몬 검사와 고해상도의 초음파검사 및 진단적 복강경 검 사의 발달로 자궁외임신의 조기진단이 가능하게 되었다. 숙련된 검사자 가 시행하는 초음파 검사가 진단에 가장 적합하다고 알려져 있기는 하 지만, 초음파 장비의 발달에도 불구하고 초음파 검사로 임신 초기에 복 강내임신을 진단하는 일은 흔하지 않다[11]. 따라서 환자가 임신 초기에 불편감을 호소하는 경우 검사자가 의심의 경계를 늦추지 않는 일이 진 단에 중요하다. 컴퓨터단층촬영으로 자궁외임신을 진단한 몇몇 증례가 보고되어 있는데, 컴퓨터단층촬영은 초음파나 자기공명영상에 비해 태 반 위치가 명확히 보이기는 하지만 태아에 대한 방사선 노출 때문에 한 정된 경우에만 시행할 수 있다는 단점이 있다[12]. 자기공명영상은 초음 파 검사에서 확인하기 어려운 복강 내 태반의 위치를 볼 수 있고, 고형 장기에 부착된 태반을 발견하기 용이하다. 태반 부착을 확인하는 것은 수술 시 태반 제거를 시도할 때 다량의 출혈이 발생할 수 있으므로 매우 중요하다. 자기공명영상이 이처럼 중요한 정보를 제공하는 동시에 방사 선 노출과 수술에 따른 위험성을 피하는 장점이 있기는 하지만 초기 임 신에서는 명확한 진단이 어렵고 전치 태반, 지궁 근종 들과의 감별 진 단이 어려운 것으로 보고되고 있다[13]. 결국 복강내임신은 자궁외임신 의심하에 시행되는 시험적 개복이나 복강경수술에 의해 거의 진단이 이루어지며, 수술 전 진단된 경우는 거의 없다고 한다.

상기 환자의 경우도 증상이 경미한 하복통 이외에는 없으며, 일반적 인 자궁외임신에서 보이는 증상과는 완전히 다른 다량의 질 출혈이 있 으면서 혈복강 소견이 없었으나, 초음파에서는 마치 우측 난관 임신처 럼 보여 증상과 진단이 맞지 않아 혼동이 많이 되었던 증례로 결국 복강 경적 수술 통해 진단이 되었다. 컴퓨터단층촬영을 했더라면 미리 진단 했을 가능성도 있으나, 시행하지 못해 진단이 늦어졌다. 이상적인 수술 방법은 복강경 또는 개복을 통해 후복막 부위 종괴 제거수술을 시행하 는 것이다. 임신낭이 붙어 있는 위치에 따라 지혈이 불가능하거나 후복 막에 위치한 큰 혈관에 손상을 주는 경우 자궁절제를 시행하거나 추가 수술이 불가피하다. 주수가 12주 이상의 복강내임신의 경우 수술 중 태 반이 남았을 때 태반의 처리에 대해서도 논란이 있다. 태반으로 가는 혈 류가 안전하게 결찰된다면, 태반을 완전히 제거하는 것이 술후 회복이 빠르므로 대부분의 연구에서 이를 권고하고 있다. 태반을 완전히 제거 하기 어려워 부분적으로 제거할 경우 대량 출혈과 쇼크를 일으킬 수 있 어 이런 상황에서는 태반을 남겨두는 것이 권고된다. 복강 내 태반을 남 겨둘 경우 종종 장폐색증, 복막염, 농양이 발생하기도 하며, 재원기간 연 장, 태반을 제거하기 위한 이차 수술 등이 필요할 수 있다. 일부 연구자 들은 태반을 그대로 남겨두고 후에 메토트렉세이트를 사용할 것을 주장 하기도 하는데, 복강 내에서 태반이 급속히 파괴되면서 태반 괴사 물질 이 축적되어 감염을 일으키는 경우가 종종 있다[14]. 후복막임신의 약물 치료에 대한 보고는 있으나 모두 실패한 것으로 보고되어 있고, 결국은 복강경 혹은 개복을 통해 수술적으로 치료한 경우이다[15].

상기 환자의 경우 난관임신으로 오인하여 약물치료를 했으나, 결국
약물치료에 실패하였는데, 저자의 생각으로는 후복막 자체에 혈관 분 포가 적어 전신적으로 투여한 약물의 도달이 어려워 약물에 잘 반응하 지 않는 것은 아닌가 생각된다. 워낙 후복막임신의 보고가 적고 임신 초 기 술 전 진단이 어려워 약물 치료 성공 증례 발표의 보고가 없어 앞으 로 치료에 있어 더 많은 연구가 필요할 것으로 보인다. 저자 등은 내원 3 주 전 무월경 5 주에 소파수술 후, 특이소견 없이 지내던 26세 여성에 서 일반적인 자궁외임신에서 볼 수 없는 급작스런 다량의 질 출혈로 자 궁외임신으로 진단 후 메토트렉세이트 다회 요법을 시행하였으나, 융모 생식샘 자극호르몬 증가 소견 보여 복강경을 시행하여 후복막에 착상된 자궁외임신으로 최종 진단하여 치료한 매우 드문 예를 경험하여 간단한 문헌 고찰과 함께 보고하는 바이다.

\section{References}

1. Lee JW, Sohn KM, Jung HS. Retroperitoneal ectopic pregnancy. AJR Am J Roentgenol 2005;184:1600-1.

2. Martin JN Jr, Sessums JK, Martin RW, Pryor JA, Morrison JC. Abdominal pregnancy: current concepts of management. Obstet Gynecol 1988;71:549-57.

3. Park $S, N a$ Y, Jung J, Yang $S$, Choi $S$, Kim $S$, et al. A clinical study of ectopic pregnancy during recent 8 years. Korean J Obstet Gynecol 2009;52:245-52.

4. Leikin $E$, Randall HW Jr. Hydrocephalic fetus in an abdominal pregnancy. Obstet Gynecol 1987;69:498-500.

5. Mbura JS, Mgaya HN. Advanced abdominal pregnancy in Muhimbili Medical Centre, Tanzania. Int J Gynaecol Obstet 1986;24:169-76.

6. Pelosi MA, Apuzzio J. Surgical management of abdominal pregnancy. Contemp Obstet Gynecol 1988;32:144-5.

7. Atrash HK, Friede A, Hogue CJ. Abdominal pregnancy in the United States: frequency and maternal mortality. Obstet Gynecol 1987;69:333-7.

8. Clark JF, Guy RS. Abdominal pregnancy. Am J Obstet Gynecol 1966;96:511-20.

9. Alexander MC, Horger EO 3rd. Early diagnosis of abdominal pregnancy by ultrasound. J Clin Ultrasound 1983;11:45-8.

10. Delke I, Veridiano NP, Tancer ML. Abdominal pregnancy: review of current management and addition of 10 cases. Obstet Gynecol 1982;60:200-4.

11. Partington CK, Studley JG, Menzies-Gow N. Abdominal pregnancy complicated by appendicitis. Case report. Br J Obstet Gynaecol 1986;93:1011-2.

12. Lee LL, McGahan JP. Combined use of ultrasound and computed tomography in evaluation of intraabdominal pregnancy 
and fetal demise. J Comput Assist Tomogr 1984;8:770-1.

13. Lockhat F, Corr P, Ramphal S, Moodley J. The value of magnetic resonance imaging in the diagnosis and management of extra-uterine abdominal pregnancy. Clin Radiol 2006;61:264-9. nancy. Can J Surg 1976;19:359-61.

15. Okorie CO. Retroperitoneal ectopic pregnancy: is there any place for non-surgical treatment with methotrexate? J Obstet Gynaecol Res 2010;36:1133-6.

\section{후복막에 착상된 자궁외임신의 복강경적 치료 1 예}

\section{순천향대학교 의과대학 산부인과학교실}

박보라, 이나혜, 안치옥, 심현진, 조은규, 김윤숙, 배동한

자궁외임신은 전체 임신의 약 $2 \%$ 를 차지하며, 임신 초기 임신과 관련된 사망률의 대부분을 차지한다. 초기 진단은 주로 베타 사람 융모 생식샘 자극호르몬 검사와 초음파로 이루어진다. 난관에 발생하는 빈도가 가장 많고, 그 다음 간질부, 자궁각, 난소, 자궁경부, 제왕절개부 위, 그리고 복강에도 발생한다. 후복막에 발생하는 자궁외임신은 매우 드물어, 대개 3,372에서 7,931분만당 1예의 발생빈도를 보이며, 수 술 전 진단은 매우 어려우며, 치료는 수술적 제거이다. 내원 3주 전 무월경 5 주에 소파수술 후, 갑작스런 질 출혈로 내원한 26세 여성에서 자궁외임신으로 진단 후 메토트렉세이트 다회 요법을 시행 후 실패하여 복강경 통해 후복막에 착상된 자궁외임신으로 최종 진단하여 치 료한 매우 드문 예를 경험하여 간단한 문헌 고찰과 함께 보고하는 바이다.

중심단어: 복강경, 후복막, 자궁외임신 